\title{
WOMEN'S LINGUISTIC FEATURES IN TWO DRAMAS
}

\author{
Aifi Umdatun Khoirot ${ }^{1}$, Zuliati Rohmah ${ }^{2}$, Desi Puspitasari ${ }^{3}$ \\ Yayasan al-Uswah Bangil, Pasuruan ${ }^{\mathbf{1}}$, UIN Sunan Ampel Surabaya ${ }^{2}$, \\ Universitas Trunojoyo Madura (UTM) ${ }^{3}$ \\ el_fakirah@yahoo.co.id ${ }^{1}$,zettira@gmail.com²,puspitasaridesi13@gmail.com³
}

\begin{abstract}
The present paper aims at describing linguistic features of two women who have two different characteristics - feminine and less feminine-as apparent in "Who's Afraid of Virginia Woolf" and "The Lover" dramas. Using Robin Lakoff's (1975) women's linguistic features, the research found out that not all features occur in the dialogues of the two female characters with other characters. Nine features were applied by Martha in "Who's Afraid of Virginia Woolf" drama and seven features were used by Sarah in "The Lover." Based on the analysis of the data, it is uncovered that the use of the women's linguistic features reflects uncertainty and lacking of confidence on the part of the women in their conversation.
\end{abstract}

Keywords: women's linguistic features; drama.

\section{INTRODUCTION}

Women's linguistic features are several aspects of speech difference between women and men which indicate the characteristic of women's speech. Woman as described by Hornby (1989) in Oxford Advanced Learner's Dictionary is an adult female human being or female sex. Lakoff (in Coates, 1986:112-113) provides a list of ten linguistic features which characterize women's speech: lexical hedges or filler, tag question, rising intonation on declarative, empty adjective, precise color terms, intensifier, hypercorrect grammar, super polite forms, emphatic stress, and avoidance of strong swear word. Lakoff also divides the ten linguistic features into two groups, that is, hedging devices and boosting devices (Holmes, 1992:316). Hedging devices are the linguistic devices that are used to reduce or minimize the force of an utterance, for example lexical hedges, tag questions, question intonation, super polite forms, and euphemisms. Boosting devices are the features used to intensify or strengthen a proposition's force, for example, intensifiers and emphatic stress.

In a certain situation, women speak differently from men in various speech communities. It is often aimed to protect their face and their addressee's face. Women and men make different use of linguistic resources available to them (Coates, 1995:13; Rudman, 1996:1). More specifically, women's speech is characterized with tag questions, rising intonation, whiny, breathy or high-pitched voices (Romaine, 1994; Cameron, 1995; Fasold, 1990). Holmes (2000) also summarizes women's styles as indirect, conciliatory, facilitative, collaborative, talking less than men, having difficulty getting a turn, person-oriented, and affectively oriented as opposed to men's styles which are being direct, aggressive, 
competitive, autonomous, dominating, interrupting aggressively, task oriented, and referentially oriented.

Related to the tendency in having collaboration and opposition among women and men, the previous researches showed that men were believed to be more aggressive and competitive than women; women were believed to be more yielding and cooperative than men (Kramarae \& Treichler, 1990; Weinrich-Haste in Thomas, 1990; Miller, 1992; Coates, 1995; Tannen, 1998; de Klerk \& Hunt, 2000). Tannen (1998) states her proposition that if ritual opposition exists more to men than women, it is just ordinary that public discourse tends to be oppositional. She explains that the difference of tendencies between boys and girls results in the difference of their competence in speaking up in public:

These different patterns--the girls' inclination to hide their conflict, the boys' to make it into a kind of performance--might explain why middle-class girls are reluctant to talk in front of others--for example, in school--and why many adult women find it hard to speak up at meetings (Tannen, 1998:203).

Based on this, the present study would like to uncover whether Martha and Sarah show women's linguistic features. Martha in Who's Afraid of Virginia Woolf and Sarah in The Lover are middle-aged women having dissimilar characters. Martha is a drinker, smoker and bad-tempered. Martha has a strong emotion and a lot of struggle to get her right as a daughter of the president of a small New England college and a wife of George. Dissimilar to Martha, Sarah is a house wife and a feminine woman; she is calmer and softer than Martha. Martha uses more swear words because Martha has stronger emotion than Sarah. Our society often does not seriously consider female as an individual with all her characters (Lakoff, 1975; Cameron, 1990). If a woman is allowed to show her emotions openly, others may be able to view her as a real individual in her own right. By studying the two different characters, this paper would like to enrich the discussion whether two female characters having different tendencies still show women's linguistic features.

Who's Afraid of Virginia Woolf by Edward Albee was first published in the U.S.A. in 1962. It was published in Great Britain by Jonathan Cape in 1964. It was published in Penguin Books 1965, and reprinted in 1966, 1967, 1968, 1970, and 1972. Made and printed in Great Britain by Cox and Wyman Ltd, London. The second drama is The Lover by Harold Pinter. The Lover was first presented by Associated- Rediffusion Television, London on 28 March 1963. The play was first presented on the stage by Michael Codron and David Hall at the Art Theater on 18 September 1963, and it was produced at the young Vic in June 1987. In short, both dramas were published in early 1960s. 


\section{RESEARCH METHODS}

Content analysis was applied to collect and analyze the data in this research. Krippendorff (1980) mentions that content analysis is a research technique for making replicable and valid inferences from data to their context (in Prasad, 1994:71-89). Krippendorff (2004:3) also states, "Content analysis entailed a systematic reading of a body of texts, images, and symbolic matter, not necessary from an author's or user's perspective". Furthermore, Kerlinger (in Prasad, 1994:71-89) defines content analysis as a method of studying and analyzing communication in a systematic, objective, and quantitative manner for the purpose of measuring variables. Weber (1985) also says it is a research methodology that utilizes a set of procedures to make valid inferences from text. In addition, content analysis is a research method to determine the presence of words or concepts in the text or a set of text to get a conclusion.

The data were words, phrases, clauses and sentences taken from Martha's utterances in Who's Afraid of Virginia Woolf and Sarah's in The Lover. To collect the data, the researcher, first identified them by underlining the words, phrases, clauses, and sentences produced by Martha which imply woman-specific linguistic features. The same was also done to Sarah's. Then, the researcher assigned codes to the identified data. After the data had been identified and coded, they were analyzed by classifying them. Then, they were interpreted based on their contexts to reveal the messages conveyed by the utterances. And finally, they were concluded to uncover what those features reflected.

\section{RESULTS AND DISCUSSION}

This part presents the use of women's linguistic features by Martha and Sarah as apparent in Table 1. There are a hundred utterances used by Martha and ninety-six utterances used by Sarah, which reflect women's linguistic features. The findings of this research show there are nine women's linguistic features reflected by Martha's utterances, namely lexical hedges or fillers, tag questions, rising intonation on declaratives, 'empty' adjectives, precise color terms, intensifier, super polite forms, avoidance of strong swear words and emphatic stress. Meanwhile, Sarah's speech redirected seven women's linguistic features, they are, lexical hedges or fillers, tag questions, rising intonation on declaratives, 'empty' adjectives, intensifier, super polite forms, and avoidance of strong swear words. 
Table 1. Women's Linguistic Features of Martha's and Sarah's Utterances

\begin{tabular}{lcccc}
\hline $\begin{array}{l}\text { Lakkof's Women's } \\
\text { Linguistic Features }\end{array}$ & $\begin{array}{c}\text { Martha } \\
(\mathbf{1 0 0} \mathbf{~ U )}\end{array}$ & $\begin{array}{c}\text { Sarah } \\
\mathbf{( 9 6} \mathbf{~ U )}\end{array}$ & $\begin{array}{c}\text { Total } \\
(\mathbf{U})\end{array}$ & $\begin{array}{c}\text { Percent } \\
\text { age }\end{array}$ \\
\hline \hline Lexical hedges or filler & 51 & 38 & 89 & $45.40 \%$ \\
\hline Intensifiers & 9 & 22 & 31 & $15.81 \%$ \\
\hline Tag questions & 4 & 14 & 18 & $9.19 \%$ \\
\hline Emphatic stress & 13 & - & 13 & $6.63 \%$ \\
\hline $\begin{array}{l}\text { Rising intonation on } \\
\text { declaratives }\end{array}$ & 4 & 8 & 12 & $6.12 \%$ \\
\hline $\begin{array}{l}\text { Avoidance strong swear } \\
\text { words }\end{array}$ & 11 & 1 & 12 & $6.12 \%$ \\
\hline Super polite forms & 3 & 7 & 10 & $5.10 \%$ \\
\hline Empty Adjectives & 2 & 6 & 8 & $4.10 \%$ \\
\hline Precise color terms & 3 & - & 3 & $1.53 \%$ \\
\hline Hypercorrect grammar & - & - & - & $0 \%$ \\
\hline Total & & & $\mathbf{1 9 6}$ & $\mathbf{1 0 0}$ \\
\hline
\end{tabular}

Note: $\mathrm{U}=$ utterance

\subsection{Lexical Hedges or Fillers}

Hedges are linguistic form such as perhaps, I think, sort of, and you know, while well and you see are described as meaningless particles and assigned to same category as pause fillers such as $u h$, ah, um, etc. Filler itself is a phrase which can appear anywhere in a sentence and which can be deleted from the sentence with no change in context.

Excerpt 1

Nick : Honey...

Honey : Well, you were.

Martha : You look like you still got a pretty good body now, (573) too... is that right? Have you?

George : Martha... decency forbids...

Martha : SHUT UP! well, have you? have you kept your body?

Nick : It's still pretty good. I work out.

Martha : Do you!

Nick : Yeach.

Honey : Oh, yes... he has a very... firm body.

Martha : Have you! Oh I think that's very nice.

Nick : Well, you never know...

Martha : .... you never know when it's going to come in handy. (Who's Afraid of Virginia Woolf, 1962, 37-38)

Excerpt 2

Richard : Is your lover coming today?

Sarah : Mmnn.

Richard : What time?

Sarah : Three.

Richard : Will you be going out... or staying in?

Sarah : Oh... I think we'll stay in. 
Richard : I thought you wanted to go that exhibition.

Sarah : I did, yes... but I think I'd prefer to stay in with him today.

Richard : Mmn-hmmn. Well, I must be off.

(The lover, 1963:2)

In those excerpts, both Martha and Sarah use 'I think'. Holmes (1990) asserts that "I think" may be used to express uncertainty (epistemic modal meaning) or as a softener to express politeness (affective meaning). The sentence in excerpt 1, turn 580 "Have you! Oh $I$ think that's very nice". It is uttered by Martha to Nick. Nick is Martha's old friend and he was married to Honey. Nick is more handsome than George. Martha and Nick had not seen each other for long time. When Nick and Honey dropped in Martha's house, she asked about Nick's condition. Then, Nick answered that he was still pretty good. Martha responded, "Have you! Oh I think that's very nice”. In this context, the function of "I think" is to show uncertainty.

In addition, based on women's linguistic features theory which is proposed by Lakoff (1975) "I think" is often used as a booster by women. In excerpt 2, turns 6 and 8, the word "I think" is used by Sarah to express a positive politeness. In the living room, Richard tried to ask Sarah and gave her a choice, while Sarah was emptying and dusting ashtrays in the living room. Sarah responded, “Oh... I think we'll stay in", and "I did, yes... but I think I'd prefer to stay in with him today". Sarah preferred staying at home than going out and she was waiting for her lover to come to her house. Sarah made an affair with another man but she did not know that her boyfriend was her husband who was pretending to be another man. So, actually she was making an affair with her own husband.

Therefore, Sarah used "I think" to express positive politeness while Martha to express uncertainty. Although both Martha and Sarah used the same expression "I think", the utterance has different functions.

\subsection{Intensifiers}

Intensifier such as so, just, very, really and quiet reflect another characteristic of women's language. "Just" can be used to minimize the imposition on the addressee. It may also have the meaning like exactly, only, and merely. Lakoff (in Cameron, 1990:23) said that "substituting an equative like so for absolute superlative (like very, really, utterly) seem to be a way of backing out of committing oneself strongly to an opinion, rather like tag questions".

Excerpt 3

George : What's what from?

Martha : I just told you; I just did it. 'What a dump!' Hunh? What's that from? 
George : I haven't the faintest idea what..

Martha : Dumbbell! It's from some goddamn Bette Davis picture ... some goddamn Warner brothers epic •.•

George : I can't remember all the pictures that $\bullet$.

Martha : Nobody's asking you to remember every single goddamn

Warner Brothers epic $\bullet \cdot$ just one! One single little epic! Bette Davis gets peritonitis in the end ... got this big black fright wig she wears all through the picture and she gets peritonitis, and she's married to Joseph Cotten or something (Who's Afraid of Virginia Woolf, 1962, 11)

\section{Excerpt 4}

Richard : Have you really?

Sarah : Mmnn

Richard : Perceptive.

Sarah : But quite honestly, I can really believe she's just... what you say.

Richard : Why not?

Sarah : It's just not possible. You have such taste. You care so much for grace and elegance in women.

(The Lover, 1963:9)

Martha used intensifiers just, too and really to show that she is backing out of committing herself strongly to an opinion as explained in excerpt 3. Sarah used intensifiers really, just, so much and very as in her utterance in excerpt 4, turn 147 "It's just not possible. You have such taste. You care so much for grace and elegance in women". There are two intensifiers in her utterances, namely just and so much. Sarah used intensifier just to show that she spoke strongly to her opinion. In addition, Sarah applied the word just to show that what she was saying is not of great importance, thus it minimizes the imposition on Richard.

\subsection{Tag Question}

Tag questions are grammatical structures in which a declarative is followed by an attached interrogative clause or tag. Tag questions added to the end of a statement do not change the statement, although they do seek an agreement. They can be used, among others, to look for some information or request, to introduce a new topic, to encourage other speaker to participate in talk, and to invite someone to tell a story.

Excerpt 5

Martha : I like your anger. I think that's what I like about you most ..• your anger. You're such a ... such a simp! You don't even have the ... the what?

George : $\cdots$ guts?

Martha : PHRASEMAKER! [Pause . $\bullet$ then they both laugh.] Hey, put some more ice in my drink, will you? You never put any ice in my drink. Why is that, huhh?

George : I always put ice in your drink. You eat it, that's all. It's that habit 
you have... chewing your ice cubes ... like a cocker spaniel.

You'll crack your big teeth.

(Who's Afraid of Virginia Woolf, 1962:16)

\section{Excerpt 6}

Sarah : Richard...You won't be home too early today, will you?

Richard : Do you mean he's coming again today? Good gracious. He was here yesterday. Coming again today?

Sarah : Yes.

Richard : Oh. No, well, I won't be home early. I'll go to the National Gallery.

Sarah : Right.

(The Lover, 1963:15)

In excerpt 5, a tag question is one of the examples of women's insecurity and hesitancy and linguistic forms with tentativeness to show that women use more tag questions than men. In excerpt 5, turn 117 shows that Martha is a drunker woman. She was in unconscious condition, she laughed while drinking and said that George never gave her a drink. Like this utterance "PHRASEMAKER! Hey, put some more ice in my drink, will you? You never put any ice in my drink. Why is that, huhh?" It was Martha's utterance to George. Martha applied a tag question to express uncertainty. She was unconscious that George always gave her a drink because she was speaking in drunken condition. Besides to express uncertainty, Martha also applied a tag question to express a request to show politeness as women's language.

Different from Martha, Sarah applied a tag question in excerpt 6 which is mentioned in turn 224 to show a softening or positive device, like the sentence "Richard...You won't be home too early today, will you?" which was uttered by Sarah. The function of tag questions in this context is to show positive devices to be more polite than man. Sarah used a tag question to get information if her husband goes home early or not. So, the writer can conclude both Martha and Sarah used tag questions to express politeness.

\subsection{Emphatic Stress}

Emphatic stress is boosting devices used to strengthen the meaning of the utterance. It has similarity with intensifiers; both reflect the use of absolute superlative. Another meaning of emphatic stress is a question intonation on sentence which is actually not a question. This is a central idea as women are powerless or weak. Women prefer to use emphatic stress to emphasize the utterance. For example:

Excerpt 7

Martha : Our son does not have blue hair .• or blue eyes, for that Matter.

He has green eyes $\bullet$ like me.

George : He has blue eyes, Martha.

Martha : Green. 
George : Blue, Martha.

Martha : GREEN! He has the loveliest green eyes ... they aren't all flaked with brown and grey, you know.$\cdot$ hazel ... they're real green ..• deep, pure green eyes ... like mine. ,"

Nick :Your eyes are ... brown, aren't they?

Martha : Green! Well, in some lights they look brown, but they're green.

Not green like his ... more hazel. George has watery

blue eyes ... milky blue.

(Who's Afraid of Virginia Woolf, 1962:50)

From those utterances, the researcher can explain that Martha emphasized the word Green and repeat it until four times. Martha used emphatic stress to strengthen the meaning of the utterance. Another emphatic stress will be showed in the following excerpt.

\section{Excerpt 8}

George : Good'Lord, Martha $\bullet \bullet$ do you know what time it ... Who's coming over?

Martha : What's-their-name.

George : Who?

Martha : WHAT'S-THEIR-NAME!

George : Who what's-their-name?

Martha : I don't know what their name is, George.••• You met them tonight $\cdots$ they're new $\cdots$ he's in the math department, or something•.••

George : Who. $\bullet$. who are these people?

Martha : You met them tonight, George.

(Who's Afraid of Virginia Woolf, 1962:14)

The sentence "WHAT'S-THEIR- NAME" is classified as emphatic stress. It is signed with capital letters and repetition to emphasize the meaning. Repetition may also be used to cover disagreement. It occurs when women want to strengthen an assertion. In stressing the opinion in written text, it may use italic, bold, coloring, repeat, capital letter, or typing with longer row of letters to give more emphasis or to strengthen the words' effect.

\subsection{Rising Intonation on Declarative}

Rising intonation on declarative is a statement using rising final intonation as used for questions, rising at the end of the statement. It not only has the form of declarative answer to question, but also the rising inflection typical of yes or no question and seems like being especially hesitant.

Excerpt 9

Martha : You met them tonight, George.

George : I don't remember meeting anyone tonight....

Martha : Well you did... will you give me my drink, please...He's in the match department... about thirty, blond, and...

George : $\bullet \bullet$ and good-looking..••

Martha : Yes. •• and good-looking.••

George : It figures. 
Martha : $\cdots$ and his wife's a mousey little type, without any hips, or Anything.

George : Oh

Martha : You remember them now?

George :Yes, I guess so, Martha... but why in God's name are they coming over here now?

(Who's Afraid of Virginia Woolf, 1962:14)

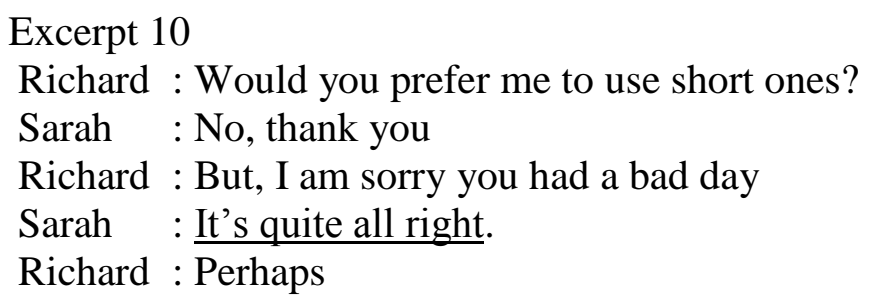

(The Lover, 1963, p. 3)

Martha's and Sarah's utterances can be categorized into one of the characteristics of women's language which relates to the special use of syntactic rule. The utterance in excerpt 9 which is written in turn 77, "you remember now?" is uttered by Martha. Martha asked George, and George responded by saying 'yes' but her question was without mentioning WH question because it is typical yes or no question. Lakoff found in English language that it can be involved to the peculiar sentence intonation which has the form of a declarative answer to a question, but it has rising inflectional typical of yes no question or rising intonation on declarative.

It is also applied by Sarah in excerpt 10 and turn 340, "It's quite all right" Richard answered "perhaps". It sounds unsure. Here we find unwillingness to assert an opinion carried to an extreme. The consequence is that this kind of speech pattern is used to reflect something real about Richard's saying, she is not sure of her self. This kind of sentence intonation pattern usually occurs among women and reflects being hesitant. Martha and Sarah seem to be lack of certainty in conveying their utterances. It indicates that there is unwillingness to assert their opinion.

\subsection{Avoidance of Strong Swear Words}

Swearing is a kind of interjection that can express extreme intensity. In other words, avoidance of strong swear words are avoiding using strong expletive expression. It has been widely considered as an expression of very strong emotion (Eckert, 2003:181). It is viewed as potent language and can indeed sometimes achieve impressive effect.

Excerpt 11

Martha : You laughed your head off when you heard it at the party.

George : I smiled. I didn't laugh my head off •.• I smiled, you know? It (104) was all right.

Martha : $\underline{\text { You laughed your goddamn head off. }}$ 
Geore : It was all right....

(Who's Afraid of Virginia Woolf, 1962:16)

Excerpt 12

Martha : The bit? The bit? "'That kind of language is that? What are you talking about?

George : The bit. Just don't start in on the bit.

Martha : You imitating one of your students, for God's sake? What are You trying to do? WHAT BIT?

George : Just don't start in on the bit about the kid, that's all.

(Who's Afraid of Virginia Woolf, 1962:18-19)

Excerpt 13

Sarah : Oh dear

Richard : I must say I rather suspected this would happen, sooner or later.

Sarah : How's your whore?

Richard : Splendid.

(The Lover, 1963:29)

It was found out that only one weak swear word was used by Sarah. On the other hand, in Martha's utterance the researcher found eleven weak swear words. Women usually use softer forms of swearing such as 'Oh, dear!' or 'Darn!', whereas men use the stronger swear words such as 'Dammit!' or 'Oh Shit!' like in Sarah's utterance "Oh dear". It indicates a weak swear word that is usually used by women. Martha also used weak swear words such as goddamn, god's sake, and Oh Lord and etc. Goddamn and God's sake are swear-words which are related to something religious or god.

\subsection{Super Polite Forms}

Lakoff (1975) and Cameron (1990:231) argued that in the same sense a request may be a polite command; it does not need obedience overtly, but suggest something to be done as a favor to the speaker. He believes that women's language is more polite and more refined.

Excerpt 14

Martha : May I have my drink, please? Daddy said we should be nice to Them. Thank you.

George : But why now? It's after two o'clock in the morning, and ...

Martha : Because Daddy said we should be nice to them!

George : Yes. But I'm sure your father didn't mean we were supposed to stay up all night with these people. I mean, we could have them over some Sunday or something • •

(Who's Afraid of Virginia Woolf, 1962, p. 14)

\section{Excerpt 15}

Sarah $\quad:$... Mmmmn? Would you like me to change? Would you like me to change my clothes? I'll change for you darling, Shall I?

Richard : Yes, would you like that? 


\section{Change \\ Change \\ Change your clothes. \\ (The Lover, 1963:37)}

Martha's utterance used super polite forms to show compound request in excerpt 14, such as "may I have my drink, please? Daddy said we should be nice to them. Thank you". While Sarah's utterance used polite forms to show simple request. That is showed in excerpt 15, "would you like me to change?". Martha's utterance is more polite than Sarah's utterance because Martha combined the words "may and please".

The word please is one of the linguistic realizations to express a request. A request is a polite way of asking someone to do something. This is normally used by the speaker who has lower power relations than the hearer. May, on the other hand, is suggesting. In Sarah's utterance "would you like me to change?" means that "are you willing to me to change?" although this utterance has function as a request, the decision is living up to the willingness of the addressee. That utterance as a positive question makes an implicit assumption that the addressee will answer "yes". If the question is phrased with negative like in Sarah's utterance "Can't you speak to strange girls?" the speaker seems to suggest the stronger likelihood of a negative response from the addressee. The assumption is that the addressee is freer to refuse. So, that utterance is a request which is more polite than Martha's utterance.

\subsection{Empty Adjectives}

Empty adjectives are adjectives that only convey an emotional reaction rather than specific information. Adjectives are applied to soften and add friendly elements to the sentence, although they are not adding any particular meaning to content. Empty adjectives become one of the characteristics of women's speech since they reflect women's uninvolved and out of power in uttering the sentence.

Excerpt 16

Martha : Anyway, George said he didn't want to, and Daddy was saying, 'Come on, young man ... what sort ' of son-in-law are you?' and stuff like that.

Nick : Yeah

Martha : So, while this was going on ... I don't know why I did it ... I got into a pair of gloves my self ... you know, I didn't lace 'em up, or anything ... and I snuck up behind George, just kidding, and I yelled 'Hey, George!' and at the same time I let go sort of a round-house right $\bullet$. . just kidding, you know?

Nick : Unh-hunh.

Martha : ... and George wheeled around real quick, and he caught it right in the jaw ... pow! I hadn't meant it ... honestly.

Anyway ...Pow! Right in the jaw... and he was off balance... he 
must have been... and he stumbled back a few steps, and then, CRASH, he landed... flat..in a huckleberry bush! It was awful, really. It was funny, but it was awful. I think it's colored our whole life. Really I do! It's an excuse, anyway.

(Who's Afraid of Virginia Woolf, 1963:40)

\section{Excerpt 17}

Richard : Oh, by the way... I rather wanted to ask you something.

Sarah : What?

Richard : Does it ever occur to you that while you're spending the afternoon being unfaithful to me I'm sitting at the desk going through balanced sheet and graphs?

Sarah : What a funny question.

Richard : No, I'm curious.

Sarah : You've never asked me that before.

Richard : I've always wanted to know.

(The Lover, 1963:6)

In excerpt 16, turn 616 explicitly shows that Martha used the words sweet, awful and funny in utterance "You bet your sweet life, it was awful, really. It was funny, but it was awful." The use of the words indicates that Martha used a kind of adjective which means that those only convey an emotional reaction rather than just specific information. In addition, Sarah also used the words funny and wonderful in utterances like, "What a funny question", and "Oh, how wonderful of you". She used those utterances to add friendly tone to the addressee.

Those adjectives can be considered as empty adjectives. Some of these adjectives are neutral as to the sex of the speaker; men or women may use them. Therefore, people who use these words are also considered as feminine and masculine (cited in Cameron, 1990: 228). Some of the representative lists of adjective are neutral (e.g. great, neat), others are generally related only to women (e.g. adorable, charming sweet, lovely, divine, gorgeous, cute). Lakoff stated that there are also certain empty no forceful adjectives and expletives commonly used by women but only very rarely by men such as charming, divine, adorable, sweet, and lovely, darn, and shoot (in Chaika, 1994:212). Consequently, if men use the women's adjectives, it will damage his reputation. On the other hand, if men use adjectives to show their approbation or admiration, they will be considered as uninvolved or out of power.

\subsection{Precise Color Terms}

Precise color terms deal with women's specific use to mention some colors more specifically. The fact that boys and girls are brought up differently can be considered in the use of color terms in their speech. The society always has a mental image that if a baby is dressed in pink with bonnet, she must be a girl. Therefore, the use of color words between men and women is different. Women tend to use color words which indicate femininity. 


\section{Excerpt 18}

Martha : Our son does not have blue hair $\bullet \bullet^{\bullet}$ or blue eyes, for that matter.

He has green eyes $\cdot$. like me.

George : He has blue eyes, Martha.

Martha : Green.

George : Blue, Martha.

Martha : GREEN! He has the loveliest green eyes ... They aren't all flaked with brown and grey, you know.$\cdot$ hazel ... they're real green ..• deep, pure green eyes ... like mine."

Nick : Your eyes are ... brown, aren't they?

Martha : Green! Well, in some lights they look brown, but they're green. Not green like his ... more hazel. George has watery blue eyes ... milky blue. (Who's Afraid of Virginia Woolf, 1963:50)

In excerpt 18, that conversation happened among Martha, George, and Nick. There is a different precise color terms between George's language and Martha's language. In the use of precise color term, George's language is more general than Martha's language. When George just said blue and green, Martha used more specific terms of what blue and green actually are, such as: milky blue, real green, and deep, pure green. It is mentioned in turns 792 and 794, “GREEN! He has the loveliest green eyes... they aren't all flaked with brown and grey, you know... hazel... they're real green... deep, pure green eyes... like mine. (792)”, "Green! Well, in some lights they look brown, but they are green. Not green like his...more hazel. George has watery blue eyes... milky blue (794).

Although Martha is a drunker, smoker and her language and behavior are sometimes like men's, she still used precise color terms to show that she is a woman. The researcher also finds emphatic stress in that excerpt. Martha used repetition word "GREEN" with capital letters. The emphatic stress in spoken language is expressed with certain intonation which has high rising tone, but in written text emphatic stress is signed with capital letters. From that table the researcher can compare between Martha and Sarah. In The Lover the researcher did not find precise color terms as she did in Who's Afraid of Virginia Woolf.

\subsection{Hypercorrect Grammar}

Hypercorrect grammar is the consistent use of standard verb forms. Women speak as close to standard verb forms as possible. Lakoff connects these features with each other since they all come down to the fact that women are not supposed to talk roughly or less politely than men. The finding shows that Martha in Who's Afraid of Virginia Woolf and Sarah in The Lover did not apply hypercorrect grammar. Their language is natural.

To summarize the previous findings, as mentioned before, the biggest number of Martha's and Sarah's utterances in Who's Afraid of Virginia Woolf and Sarah in The Lover 
that contains women's linguistic features is on lexical hedges or fillers which is $45.40 \%$. The use of lexical hedges is to show uncertainty and lack of confidence in the conversation. They also function as fillers in the conversation which are applied to give the speakers sequence of time to think what they will say next; to greet the addressee; and to keep the conversation on track. Martha often discussed sensitive topics which may produce strong emotions in the speakers and the addressee. In order to avoid creating arguments, she tended to hedge her assertions. Sarah, on the other hand, used hedges to show positive politeness, indicating sensitivity to others' feelings. It is interesting to note here that although Martha is less feminine, she applied more hedges and fillers than Sarah did.

Furthermore, intensifiers is the second frequent feature of women's language used by Martha and Sarah with the percentage of $15,81 \%$. Here, Sarah used more intensifiers that Martha; twenty two and nine subsequently. It shows that Martha and Sarah wanted to emphasize or strengthen their utterances deeply to attract addressee's attention using intensifier. As said by Lakoff (1975), women "use intensifying devices to persuade their addressee to take them seriously" (in Holmes, 2001: 287) because they are lacking status in society. Another stimulating point needs to be attended here is that Sarah who is more feminine than Martha applied more intensifiers. Similar tendency also occurs in tag questions. Sarah also applied more tag questions than Martha in order to appear more polite. In addition, Sarah used more rising intonation on declarative to express surprise. Sarah applied more super polite form to show her being polite, too.

Two features existing in Martha's utterances but not in Sarah's. They are precise color terms and emphatic stress. The use of italic, bold, coloring, repeat, capital letter, or typing with longer letter to give more emphasis or to strengthen the words appeared more in Martha's than in Sarah's utterances. This shows that although Martha is more masculine, her language still shows women's linguistic features. The fact that Martha avoids strong swear words more than Sarah confirms this conclusion. Swearing is kinds of interjection that can express extreme intensity. It has been widely considered as an expression of very strong emotion (Eckert, 2003:181). Martha and Sarah both convey their emotional reaction by using empty adjectives. Lakoff's women's linguistic feature which is not used by both Martha and Sarah is hypercorrect grammar.

\section{CONCLUSION}

From the research results, it can be concluded that both Martha and Sarah apply various women's linguistic features. They both put hedges more frequently than other features 
showing both their uncertainty and preferences to politeness and sensitivity to others' feelings. Although Martha is more masculine than Sarah, her language shows more women's linguistic features. Martha used precise color terms and emphatic stress, while Sarah did not. Furthermore, Sarah applied these features more frequently, i.e. intensifier, tag questions, more rising intonation on declarative, and super polite form.

\section{REFERENCES}

Albee, E. (1962). Who's Afraid of Virginia Wolf. U.S.A: Penguin Books.

Cameron, Deborah. (1990). The Feminist Critique of Language. U. S. A: Routledge.

Cameron, D. (1995). Rethinking Language and Gender Studies: Some Issues for the 1990s. In: Sara Mills (Ed.), Language and Gender: Interdisciplinary Perspectives (pp. 31-44). Horlow: Longman.

Chaika, E. (1994). Language: The social mirror. 3rd edition. Boston: Heinle \& Heinle Publishers.

Coates, Jennifer. (1989). Women Talk: Conversation between Women Friends. Oxford: Blackwell

Coates, J. (1995). Language, Gender and Career. In: Sara Mills. (1995). (Ed.), Language and Gender: Interdisciplinary Perspectives (pp.13-30). Horlow: Longman

De Klerk, V. \& Hunt, S. (2000). Discourse Domination? The Role of Gender in Seminar Interaction. Southern African linguistics and Applied Language Studies, 18, 73-87.

Eckert, P. (2003). Language and Gender. UK: Cambridge University Press.

Fasold, R. (1990). The Sociolinguistics of Language. Cambridge: B. Blackwell.

Holmes, J. (1992). An Introduction to Sosiolinguistics.UK: Longman.

Holmes, J. Women. (2000). At Work: Analyzing women's talk in New Zealand Workplaces. Australian Review of Applied Linguistics, 22, 1-17.

Holmes, J. (2001). An Introduction to Sociolinguistics. Second Edition. UK: Longman.

Hornby, A. S. (1989). Oxford Advanced Learner's Dictionary of Current English. Oxford: Oxford University Press.

Kerlinger, F.N. (2010). Foundations of behavioral research (3rd ed), New York: Holt, Rinehart and Winston, (online) 26. www.newsimproved.org/documents/Guide_to_Content_Analysis.pdf, retrieved: July 
Kramarae, C. \& Treichler, P. A. (1990). Power Relationships in the Classroom. In Susan L. G. (Ed.), Gender in the Classroom Power and Pedagogy (pp. 41-59) Urbana: University of Illinois Press.

Krippendorff, K. (2004). Content Analysis: An introduction to its methodology, London: Sage.

Lakoff, R. (1975). Language and Woman's Place. New York: Harper and Row.

Miller, J. B. (1992). Conflict Scripts of Men and Women. In Linda A.M. P., Lyn H. T., \& Helen M.S. (Eds), Constructing and Reconstructing Gender: The Links among communication, language and Gender (pp. 239-249). Albany: State University of New York.

Pinter, Harold. (1963). The Lover. London: Associated - Rediffusion Television.

Prasad, D. B. (1994). Dowry-related violence: A content analysis of news in selected papers, The Journal of Comparative Family Studies, 25(1): 71-89.

Romaine, S. (1994). Language in Society: An introduction to Sociolinguistics. New York: Oxford University Press.

Rudman, C. (1996). Frames of Reference: How Men and Women Can Overcome Communication Barriers and Increase Their Effectiveness at Work. Princeton: Peterson's/Pacesetter Books.

Tannen, D. (1998). The Argument Culture: Moving from Debate to Dialogue. New York: Random House.

Thomas, K. (1990). Gender and Subject in Higher Education. Buckingham: Open University Press.

Weber, R.P. Basic content analysis, New Delhi: Sage, (online) www.newsimproved.org/documents/Guide to_Content_Analysis.pdf (retrieved: July 26, 2010). 